\title{
DNA-binding studies of a series of novel water-soluble derivatives of 1,4-dihydropyridine
}

\author{
E. Leonova ${ }^{1}$, E. Rostoka ${ }^{1}$, L. Baumane 2 , V. Borisovs ${ }^{1,3}$, E. Smelovs ${ }^{1}$, I. Bisenieks ${ }^{2}$, \\ I. Brūvere ${ }^{2}$, E. Bisenieks' ${ }^{2}$, G. Duburs ${ }^{2}$ and N. Sjakste ${ }^{1,2}$ \\ ${ }^{1}$ Faculty of Medicine, University of Latvia \\ 1a, Sharlotes Str., Riga, Latvia, LV-1001 \\ 2 Latvian Institute of Organic Synthesis \\ 21, Aizkraukles Str., Riga, Latvia, LV-1006 \\ ${ }^{3}$ Daugavpils University \\ Vienības Street 13, Daugavpils, Latvia, LV-5401
}

\begin{abstract}
Aim. To the determine DNA interaction modes for a series of 1,4-dihydropyridines with different biological activities synthesized in the Latvian Institute of Organic Synthesis. Methods. Affinity of the compounds to DNA was detected by UV/VIS spectrometry and re-proofed by means of spectrofluorimetry, EBr extrusion assay, cyclic voltammetry and DNA melting. Radical scavenging was tested by electron paramagnetic resonance spectroscopy, peroxynitrite binding was monitored spectrophotometrically, protection of DNA against hydroxyl radical was determined by gel electrophoresis. Results. In a series of water-soluble monocyclic derivatives of 1,4-dihydropyridine with carboxylate groups in position-4 the different affinity to DNA was determined mainly by substituents in positions 3 and 5. 1,4-DHP with ethoxycarbonyl groups in positions 3 and 5 (AV-153) manifested high affinity to DNA. Strong effects were observed in the spectra of tricyclic fused derivatives (PP-150-Na and PP-544- $\mathrm{NH}_{4}$ ). Unlike AV-153, J-4-96 did not extrude EtBr from the complex with DNA, this indicates binding to minor groove. Ability of PP-544- $\mathrm{NH}_{4}$ to intercalate DNA molecule was proved electrochemically and by DNA melting. No correlation between affinity of a 1,4-DHP to DNA and capabilities of the compound to bind peroxynitrite, to scavenge hydroxyl radical or to protect DNA against the above radical were observed. Conclusions. DNA-binding activities of 1,4-DHP are evidently determined by groups in positions 3 and 5. Tricyclic fused 1,4-DHP derivatives are also good DNA binders. Ability to interact with DNA does not correlate with other effects produced by the compounds.
\end{abstract}

Ke y w o r d s: 1,4-dihydropyridines, DNA binding, peroxynitrite binding, hydroxyl radical scavenging, DNA protection.

(C) 2018 E. Leonova et al.; Published by the Institute of Molecular Biology and Genetics, NAS of Ukraine on behalf of Biopolymers and Cell. This is an Open Access article distributed under the terms of the Creative Commons Attribution License (http://creativecommons.org/licenses/by/4.0/), which permits unrestricted reuse, distribution, and reproduction in any medium, provided the original work is properly cited 


\section{Introduction}

Synthetic derivatives of 1,4-dihydropyridine (1,4-DHP) possess important biochemical and pharmacological properties. They show modulating effect on cardiovascular and neuronal processes as well as anticancer, geroprotective and radioprotective effects. Some 1,4-DHP manifest antimutagenic activity and anticlastogenic effects and stimulate DNA repair [14]. Lacidipine, ramipril and valsartan protect DNA against oxidative damage in the heart infarction zone [5]. 1,4 DHP can act also as free radical scavengers $[6,7]$ and increase bioavailability of nitric oxide [7]. Another group of 1,4-DHP derivatives generates DNA breaks, via radical or other mechanisms [8]. 1,4-DHP with positively charged groups are used as vectors for DNA delivery inside the cells [9]. Most biological effects of this class of the compounds are usually ascribed to blocking calcium channels, this can lead to multiple biological effects following different intracellular pathways, resulting in weakening of oxidative stress [10].

However, in the present investigation we have focused our attention on a group of 1,4DHP derivatives considered to be "unusual". These are the water soluble molecules with no or very weak blocking activity towards calcium channels. Some of them manifest different biological activities. Our recent results revealed DNA binding capacity of another water-soluble 1,4-DHP, the antimutagene AV-153 [11] and some other 1,4-DHPs [12]. Aim of the present work was to reveal structure-functional relations of DNA-binding capacity of water-soluble1,4-DHPs, to study the mode of the compound and DNA interactions of the most active compounds and to compare DNA-binding capacity with other activities of the compounds.

\section{Materials and Methods}

\section{Chemicals}

Water-soluble derivatives of 1,4-DHP were synthesized in the Laboratory of Membrane Active Compounds of the Latvian Institute of Organic Synthesis. The compounds structures are given in Table 1. Tris base, sucrose, ethidium bromide, acridine orange, Triton-X-100, ethidium bromide (EtBr), $\mathrm{Na}_{2} \mathrm{EDTA}, \mathrm{LiCl}, \mathrm{NaCl}, \mathrm{CaCl}_{2}$ and other inorganic salts were purchased from Sigma-Aldrich. 2-mercaptoethanol was obtained from Ferak Berlin, sodium dodecyl sulphate was supplied by Acros Organics, isoamylic alcohol was obtained from Stanlab, and $6 \times$ Orange loading solution, RNase $\mathrm{A}$ and Proteinase $\mathrm{K}$ were purchased from Fermentas. Peroxynitrite was synthesized as described [13].

\section{Isolation of DNA}

The pTZ57R plasmid was isolated from Escherichia coli DH5alpha strain transformed with this plasmid, sonicated and purified essentially as described [11].

\section{UV/VIS spectroscopic measurements}

UV-VIS spectra were recorded with a Perkin Elmer Lambda 25 UV/VIS spectrophotometer in the absence of DNA and in the presence of increasing amounts of DNA in $5 \mathrm{mM} \mathrm{NaCl}$ and $5 \mathrm{mM}$ Tris $\mathrm{HCl}$ at $\mathrm{pH} 7.4$ or other buffer. A $30 \mu \mathrm{M}$ solution of the tested compound was diluted out of a $1 \mathrm{mM}$ stock solution in the buffer in a quartz cell $(2 \mathrm{ml})$. A reference cell was filled with $1 \mathrm{ml}$ of the buffer. The mixture 
was stirred thoroughly and titrated by $1.2 \mathrm{mM}$ DNA solution, $10 \mu \mathrm{M}$ each time to both sample and reference cells. DNA molar concentration was calculated on the basis of absorbance of the solution at $260 \mathrm{~nm}$ and molar extinction coefficient for DNA. Spectra were recorded in the 400-200 nm interval at room temperature.

Binding constants were calculated by applying the formula

$$
\frac{1}{A_{0}-A}-\frac{1}{A_{0}}+\frac{1}{K \times A_{0} \times C_{\mathrm{DNA}}}
$$

according to [14], where $A_{0}$ is absorption of the free substance, $\mathrm{A}$ is absorption in [the] presence of DNA, and $\mathrm{c}_{\mathrm{DNA}}$ is DNA concentration.

\section{Fluorescence spectroscopic measurements}

Spectrofluorimetric analyses were performed on a Fluoromax-3 (Horiba JOBIN YVON). Fluorescence spectra of a $25 \mu \mathrm{M}$ solution of the 1,4-DHP in $5 \mathrm{mM}$ Tris $\mathrm{HCl} ; 5 \mathrm{mM} \mathrm{NaCl}$ at $\mathrm{pH}$ 7.4 or other buffer were recorded over a range of 240-700 nm at an excitation wavelength of $350 \mathrm{~nm}$. DNA was sequentially added up to 225 $\mu \mathrm{M}, 10 \mu \mathrm{M}$ at each step until saturation. EtBr displacement assay were carried out as described [11], with minor modifications: fluorescence intensity of the DNA-EtBr complex was recorded at $600 \mathrm{~nm}$ using an indirect excitation wavelength of $\mathrm{EtBr}$ at $260 \mathrm{~nm}$.

\section{The melting temperature}

The melting temperature (Tm) of DNA and 1,4-DNA complexes was determined by recording absorbance values at $260 \mathrm{~nm}$ at different temperatures on Unicam SP 1800 Ultraviolet Spectrometer (USA) using SP 876 Series 2 Temperature Programme Controller device and a $1 \mathrm{~cm}$ path length cell. Temperature was increased for $0.5^{\circ} \mathrm{C}$ per minute from the room temperature up to $100{ }^{\circ} \mathrm{C}$. The absorbance was recorded at $1 \mathrm{~min}, 2 \mathrm{~min}$ or $5 \mathrm{~min}$ intervals depending on intensity of changes in the given temperature range. The $50 \mu \mathrm{M}$ solutions of DNA and the tested compounds were prepared in $50 \mathrm{mM}$ Tris- $\mathrm{HCl}, 50 \mathrm{mM} \mathrm{NaCl} \mathrm{pH} \mathrm{7.4.}$

\section{Cyclic voltammetry}

Voltammetric experiments were performed using an EcoChemie Autolab PGSTAT 302T potentiostat/galvanostat (Utrecht, The Netherlands) with the electrochemical software package Nova 2.0. A three-electrode system was used: a $2 \mathrm{~mm}$-sized Pt disk working electrode, an $\mathrm{Ag} / \mathrm{AgCl}$ reference electrode $(3 \mathrm{M} \mathrm{KCl})$ and a $\mathrm{Pt}$ wire counter electrode. Electrodes were purchased from Metrohm Co (Herisau, Switzerland). 1,4-DHP solution was added to $0.1 \mathrm{M}$ Tris- $\mathrm{HCl}(\mathrm{pH}=7.4)$ solution up to a final concentration $5 \mathrm{mM}$, and voltammograms were recorded. After that $10 \mu \mathrm{M}$ of DNA was added to solution and measurements were repeated. The step was repeated at least twice. A scan rate of $100 \mathrm{mV} / \mathrm{s}$ was used throughout the experiments. All electrodes were washed with double distilled water prior to each measurement. Oxygen-free nitrogen was bubbled through the solution for $5 \mathrm{~min}$ before each experiment. All experiments were carried out at $25^{\circ} \mathrm{C}$.

The binding constant was determined according to the following equation:

$\log (1 / \mathrm{DNA})=\log (\mathrm{K})+\log \left[\mathrm{I}_{\text {free }} /\left(\mathrm{I}_{\text {free }}-\mathrm{I}_{\text {bond }}\right)\right]$,

where $\mathrm{K}$ - the apparent binding constant; $\mathrm{I}_{\text {free }}-$ the peak current of free compound; and $\mathrm{I}_{\text {bond }}-$ the peak current of compound in the presence of DNA (Feng et al. 1997). 
The number of the binding sites was determined according to the equation:

$$
\left(\mathrm{I}-\mathrm{I}_{\mathrm{DNA}}\right) / \mathrm{I}_{\mathrm{DNA}}=\mathrm{K}[\mathrm{DNA}] / 2 \mathrm{~s}
$$

where I - the peak potential of compound in the absence of DNA; A, I $\mathrm{INA}_{\text {- the peak po- }}$ tential of compound in the presence of DNA; A, $\mathrm{K}$ - the binding constant of compoundDNA complex; [DNA] - concentration of DNA, mol/L; s - number of binding sites (Aslanoglu 2006; Carter et al. 1989).

The number of electrons (n) was calculated using equation:

$$
\mathrm{Ep}-\mathrm{Ep} / 2=47.7 \mathrm{mV} / \mathrm{\alpha n}
$$

where Ep - peak potential of compound, $\mathrm{mV}$; $\mathrm{Ep} / 2$ - half wave potential of compound, $\mathrm{mV}$; $\alpha$ - the assuming value $=0,539 ; \mathrm{n}-$ number of electrons [10].

Fenton reaction - DNA protection assay pTZ57R DNA was treated with $0.003 \%$ hydrogen peroxide and $0.01 \mathrm{mM}$ iron(II) sulphate in PBS for $30 \mathrm{~min}$ at $37^{\circ} \mathrm{C}$. Induction of singlestrand breaks was monitored by electrophoresis in agarose gels in neutral conditions following conventional protocols. Briefly, $0.2 \mu \mathrm{g}$ of DNA was incubated with hydrogen peroxide and iron(II) sulphate in the presence or absence of 1,4-DHP at room temperature. Following incubation, the samples were mixed with $6 \times$ Orange loading solution and loaded onto $0.8 \%$ agarose gel containing $40 \mathrm{mM}$ Tris, $20 \mathrm{mM}$ sodium acetate and $2 \mathrm{mM}$ EDTA and electrophoresed in a horizontal slab gel apparatus in Tris/acetate/EDTA gel buffer at $30 \mathrm{~V}$. Results were presented as percentage of supercoiled and open circular DNA ([15]). Data were normalized according Kolmogorov-
Smirnov, statistical analysis was performed by one direction ANOVA and Tuckey post-test.

\section{Fenton reaction - ESR measurements}

Trapping of hydroxyl radical was performed by 5,5 -dimethylpyrroline- $N$-oxide (DMPO)spin trap. Details were published before [16].

\section{UV/VIS spectroscopic measurement of peroxynitrite decomposition}

The rate of peroxynitrite $(0.38 \mathrm{mM})$ decomposition, in the presence or in the absence of the $1,4-$ DHP $(0.16 \mathrm{mM})$ was followed at $302 \mathrm{~nm}$ (absorbance peak for the peroxynitrite anionic form) in $10 \mathrm{mM}$ Tris, $\mathrm{pH} \mathrm{10,} \mathrm{buffer} \mathrm{on}$ Perkin Elmer Lambda 25 UV/VIS spectrophotometer [17]. The average rate of reactions was calculated with $\mathrm{V}= \pm\left(\left(\mathrm{C}_{2}-\mathrm{C}_{1}\right) /\right.$ $\left.\left(\mathrm{t}_{2}-\mathrm{t}_{1}\right)\right)= \pm(\Delta \mathrm{C} / \Delta \mathrm{t}) \mathrm{C}_{1}-$ concentration of peroxynitrite in the beginning of reaction, $\mathrm{C}_{2}-$ concentration of peroxynitrite at the end of reaction; $\Delta \mathrm{t}$ : $20 \mathrm{~min}$.

\section{Results and Disussion}

\section{Absorption studies}

Absorption titration was carried out to monitor the interaction of the compounds with sonicated plasmid DNA. In a series of water-soluble monocyclic derivatives of 1,4-dihydropyridine with carboxylate groups in position 4 the compounds manifested different affinity to DNA determined mainly by substituents in positions 3 and 5. The compounds with cyano group or acetyl groups in position 3 and 5 (J-3183 and AV-154 correspondingly) did not interact with DNA. Replacement of 3,5-acetyl groups (AV-154) with methoxycarbonyl groups (J-7-53-B) did not improve the DNA binding, 
however ethoxycarbonyl groups (AV-153 Na) made the compound able to interact with DNA: a pronounced hyperchromic and bathochromic effects were observed as described previously ([11]; Table 1). Further modification of positions 3 and 5 decreased the DNA binding capacity of the compounds, it decreased almost five-fold when aromatic rings were added to ethoxycarbonyl groups (J-8-120; Table 1), and a drastic 30-fold difference was observed between compounds with ethoxycarbonyl (AV-153 Na) and propoxycarbonyl groups (J-4-96) in positions 3 and 5. Interestingly, the ethoxycarbonyl groups in positions 3 and 5 appear to determine the DNA-binding capacity in the series of our compounds with no cyclic side groups. At the same time, the same ethoxycarbonyl groups in positions 3 and 5 determine antimicrobial activity in another series of 1,4-DHP [18], thus antimicrobial activity might be due to the compound capability of binding DNA.

Capacity of interactions with DNA was strongly dependent also on substituents in position 4. Addition of alanine in position-4 as amide of 2,6-dimethyl-3,5-diethoxycarbonyl-1,4-dihydroisonicotinic acid (alapyrone) abolished an ability to bind DNA, however taurine in the same position (tauropyrone) maintained the ability to interact with DNA (Table 1).

The 1,4-DHP derivative carbatone [disodium-2,6-dimethyl-1,4-dihydropyridine-3,5-bis (carbonyloxyacetate)] unsubstituted in position 4 manifested hyperchromic effect in the presence of DNA without any spectral band position shifts, the affinity to DNA was low. However, addition of acetyl groups to positions 2 and $6(\mathrm{~J}-3-131-\mathrm{Na})$ increased [the] affinity to DNA. (Table 1).

Tricyclic fused 1,4-DHP derivatives - decahydroacridine-1,8-diones (PP-150-Na and PP$544-\mathrm{NH}_{4}$; B-5-Na) produced hyperchromic effect without any shifts (Fig. 1). PP-544-NH $\mathrm{NH}_{4}$ was the most effective DNA binder, replacement of carboxylic group in position 4 with an aromatic ring and addition of aliphatic chains

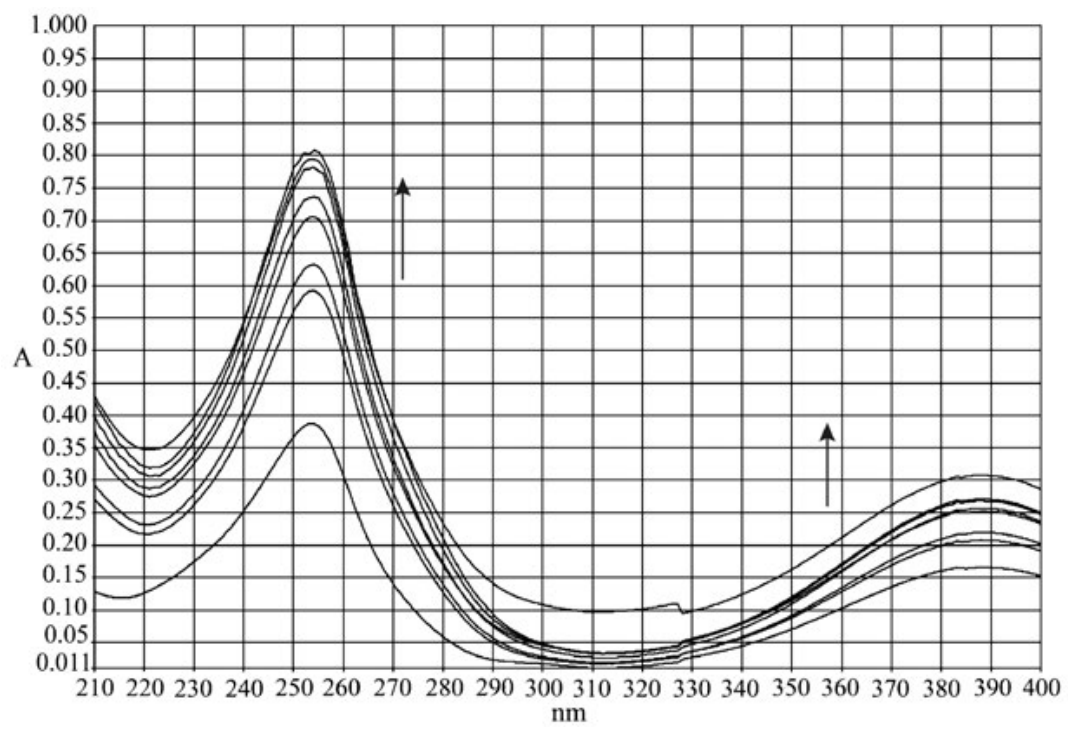

Fig. 1. UV/VIS spectra of PP-544NH4 in absence and presence of DNA added by $12.5 \mu \mathrm{M}$ at each step. 


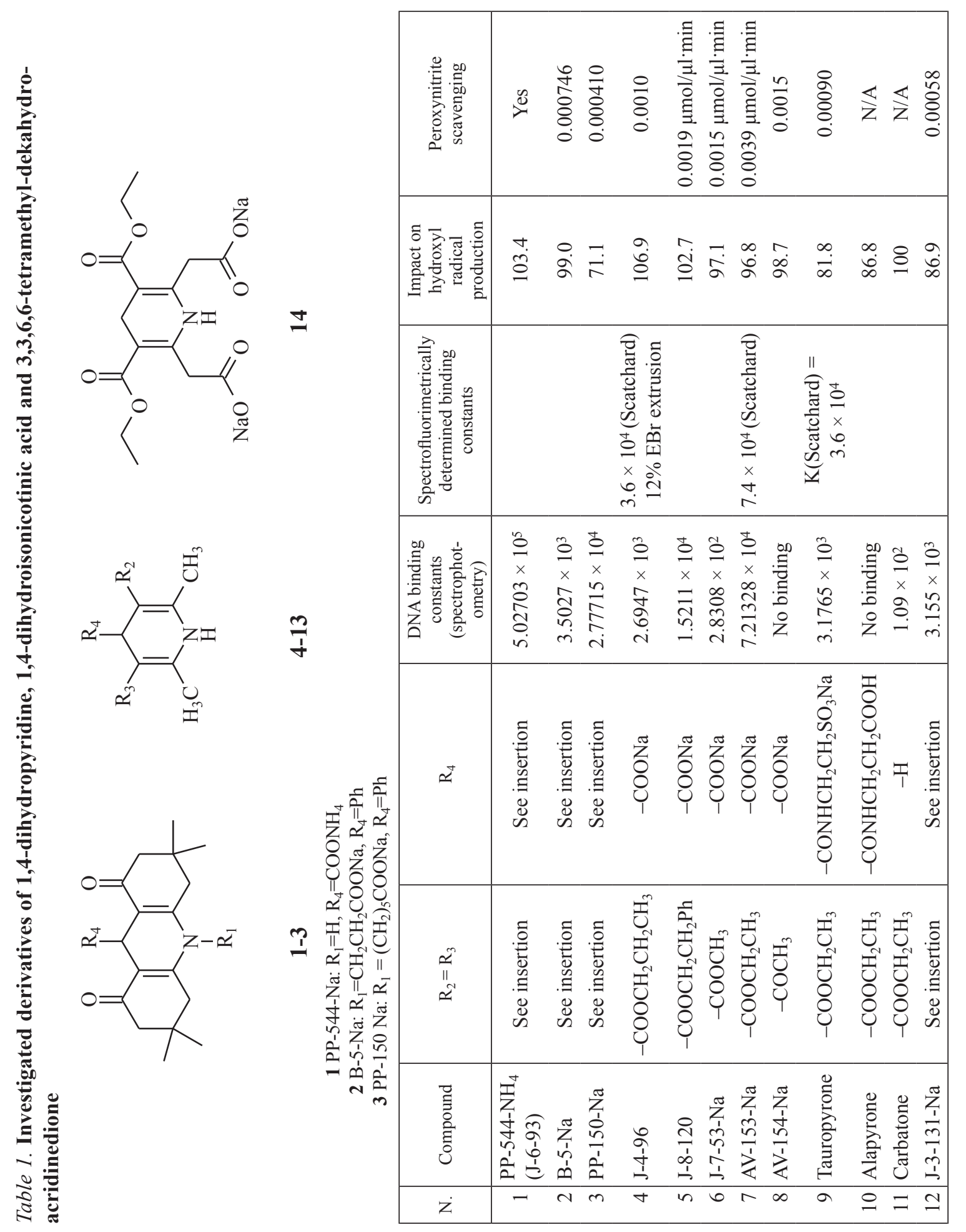


ending with a carboxylic group to nitrogen in position 1 drastically decreased the effectiveness of DNA binding (Fig. 2, Table 1). Binding constant of the PP-544- $\mathrm{NH}_{4}$ with DNA depended on the ionic strength of the solution: it increased when ionic strength raised from $10 \mathrm{mM}$ to $50 \mathrm{mM}$ and abruptly decreased at 150 and $300 \mathrm{mM} \mathrm{NaCl}$ (not shown).

Formerly it was shown that AV-153-Na binds to DNA via intercalation ([11]). For further studies we have chosen two compounds - PP-544- $\mathrm{NH}_{4}$, as it turned out to be the strongest binder among the studied and J-4-96, differing from AV-153 by length of the groups in positions 3 and 5, the latter modification drastically decreased its affinity to DNA (Table 1).

\section{Fluorescence assay}

Interactions with DNA of the PP-544- $\mathrm{NH}_{4}$, the strong DNA binder revealed by UV/VIS spectroscopy, was also confirmed by fluorescence measurements. When irradiated with excitation light at $255 \mathrm{~nm}$, the compound emitted fluorescent light at $462 \mathrm{~nm}$, intensity of the fluorescence increased when
DNA was added to the solution (Fig. 2A). These results confirm again the fact of the direct interaction between the compound and DNA, indicating decrease of fluorescence quenching effect of solvent molecules after penetration of the molecule in hydrophobic environment [19]. Interestingly, two other tricyclic compounds B-5-Na and PP-150-Na produced a different effect. Excitation maximum was at $400 \mathrm{~nm}$, emission peak - at 515 $\mathrm{nm}$. After DNA addition, the maximum emission peak underwent a red shift to 520 $\mathrm{nm}$, but without the fluorescence intensity enhancement (Fig. 2B). Compound J-4-96 with longer propoxycarbonyl groups in positions 3 and 5 compared to AV-153 and much lower affinity to DNA manifested similar changes in fluorescence spectra after addition of DNA. Besides an increase of the fluorescence intensity a red shift was observed (Fig. 3A). However unlike AV-153 the compound did not extrude EtBr out of DNA, as intensity of fluorescence of EtBr and DNA complex did not decrease significantly in presence of the compound (Fig. $3 C$ ). Apparently, the 1,4-DHP can bind DNA
A

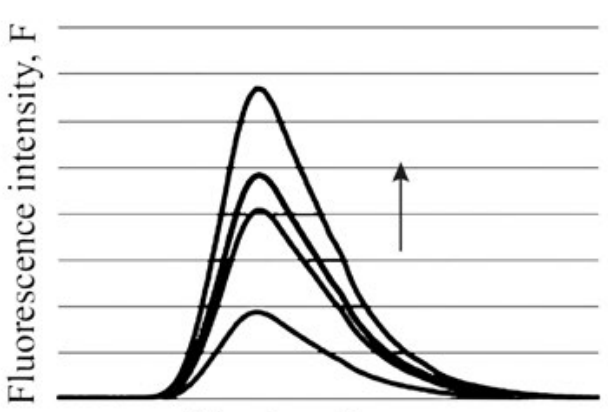

Wavelength, nm
$B$

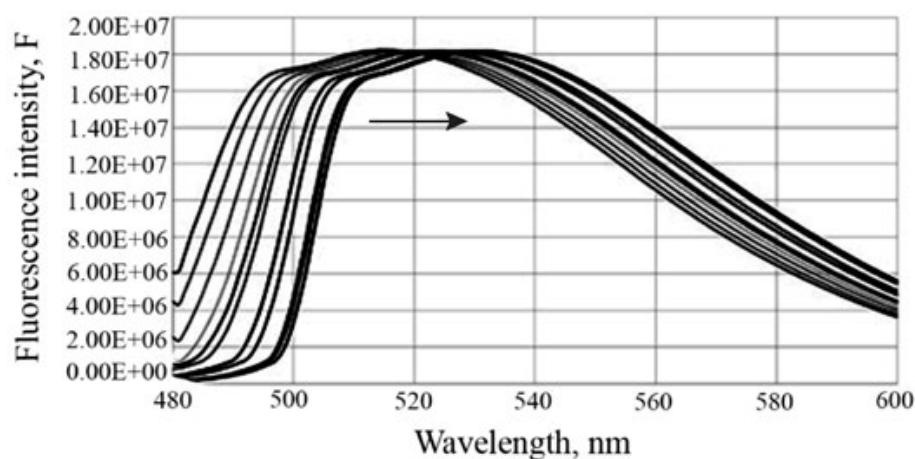

Fig. 2. $A$ - Fluorescence spectra of PP-544- $\mathrm{NH}_{4}$ with excitation at $\lambda=250$ in presence of different concentrations of DNA; $B$ - Fluorescence spectra of PP-150-Na with excitation at $400 \mathrm{~nm}, 12.5 \mu \mathrm{M}$ DNA was added at each step until saturation $(125 \mu \mathrm{M})$. Concentration of the compound was $25 \mu \mathrm{M}$. 
by different modes - intercalation, as AV-153 and minor groove binding, as weaker binders (J-4-96). Indeed, good binders could probably interact with DNA by both intercalation and DNA minor groove binding, like the berberine [20], modifications of the molecules decreasing the affinity to DNA could mainly abolish ability to intercalate.
A

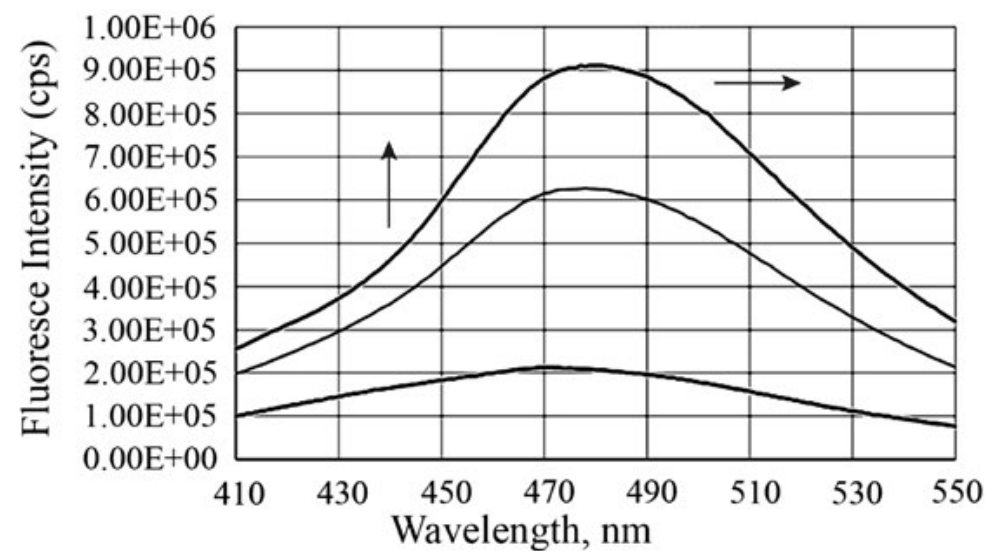

B

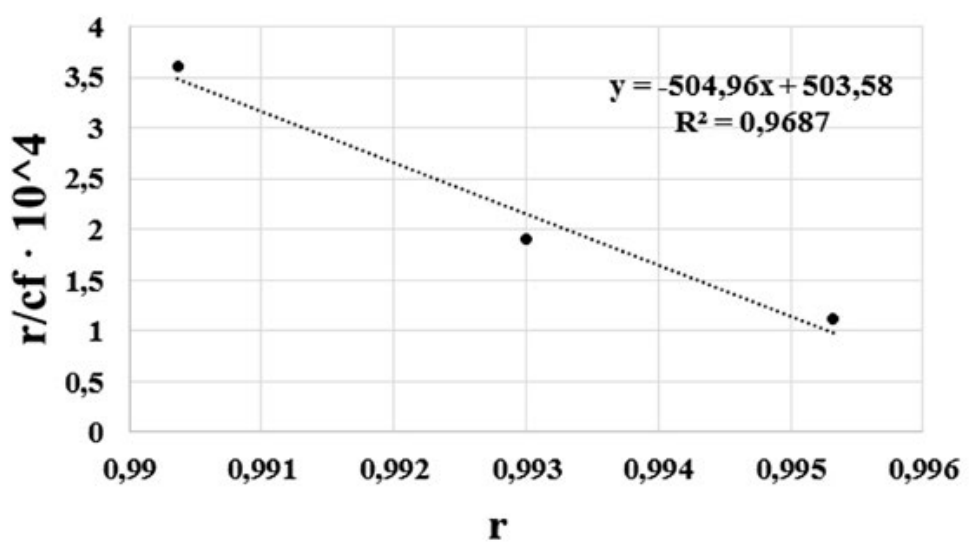

C

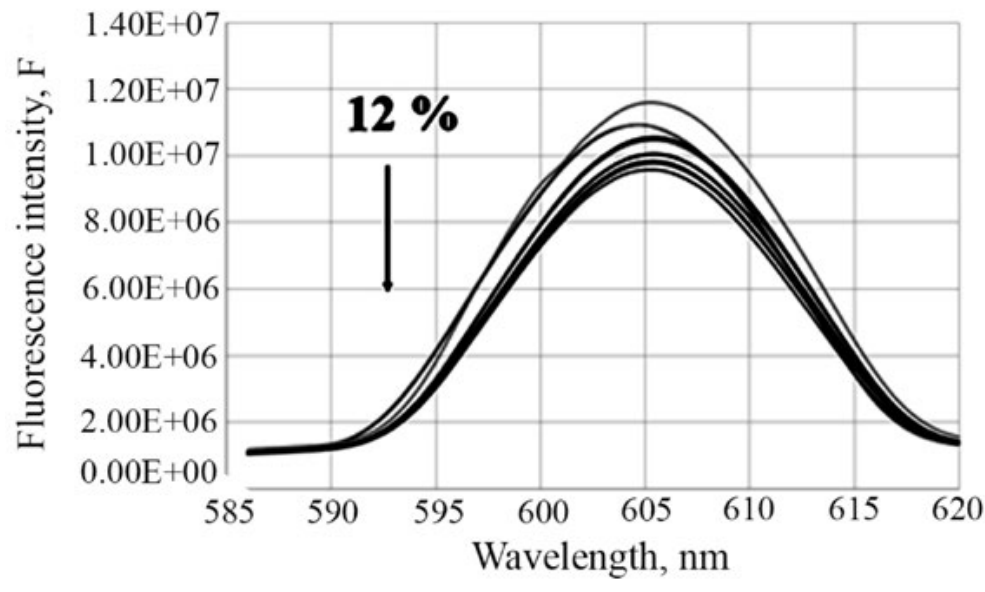

Fig. 3. $A$ - Fluorescence spectra of compound J-4-96 in presence of increasing concentration of DNA, $\lambda$ ex. $=350 \mathrm{~nm}$, $\lambda \mathrm{em} .=440 \mathrm{~nm}$. Concentration of the compound was $25 \mu \mathrm{M}$, Three of 23 taken spectra are presented, these correspond to $0,187.5 \mu \mathrm{M}$ and $275 \mu \mathrm{M}$ DNA. $B$ - corresponding Scatchard plot. $C-\mathrm{EBr}$ extrusion experiment. Fluorescence spectra of $\mathrm{EBr}$ and DNA complex in the presence of increasing concentrations of J-4-96, concentration of EBr was $12.6 \mu \mathrm{M}$, DNA $74.8 \mu \mathrm{M}, \mathrm{J}-4-96$ was added by $10 \mu \mathrm{M}$ at each step. 


\section{DNA denaturation curves}

We could not determine the mode of interaction of PP-544- $\mathrm{NH}_{4}$ with DNA using EBr extrusion assay as the measured intensity of the $\mathrm{EBr}$ and DNA complex increased when the compound was added, probably due to overlap of the wavelengths of the EBr-DNA and the tested compound emitted light. Therefore, the DNA melting experiments were performed to establish the fact of intercalation. Results are presented in Fig. 4A. In the presence of PP544- $\mathrm{NH}_{4}$ DNA melting temperature increased from $67.5^{\circ} \mathrm{C}$ to $69.5^{\circ} \mathrm{C}$ confirming intercalation in the DNA molecule. The tricyclic 1,4-DHP could be "typical" intercalators possessing a rigid three cycle skeleton, whereas judging of their structure monocyclic 1,4-DHP could be "atypical" intercalators [21].
A

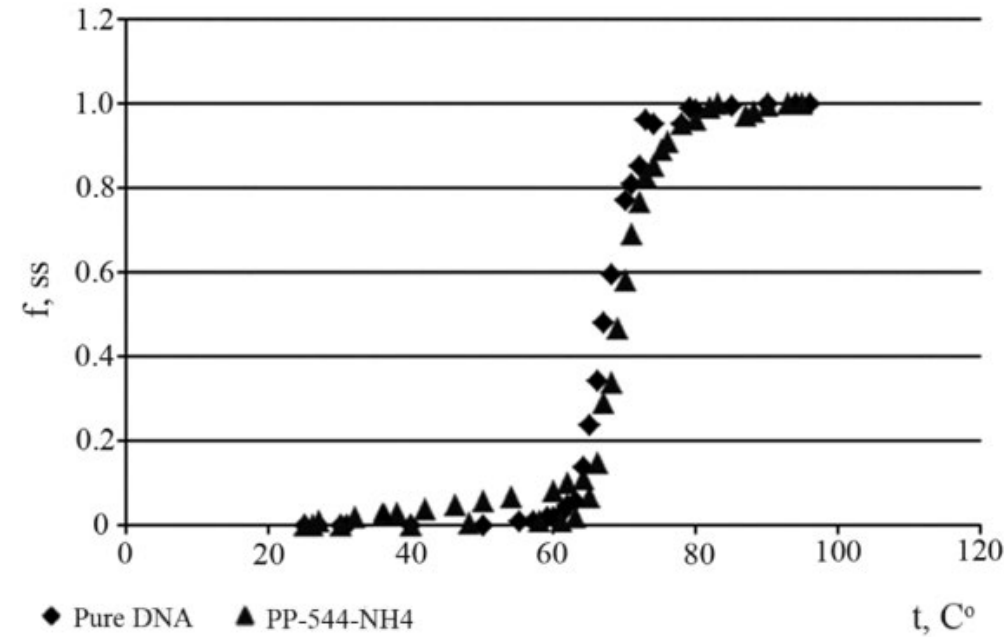

$\boldsymbol{B}$

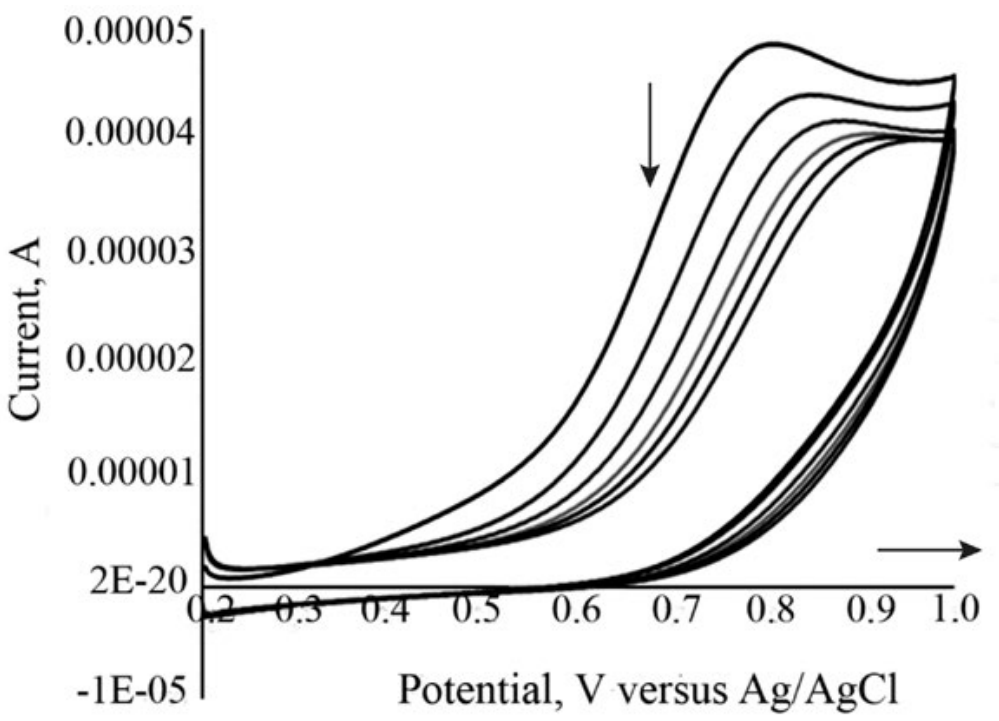

Fig. 4. $A$ - DNA melting curves in absence and presence of $\mathrm{PP}-544-\mathrm{NH}_{4}$ Concentration of both compounds was $50 \mu \mathrm{M}$; $B$ - Cyclic voltammograms of $5 \mathrm{mM}$ PP-544- $\mathrm{NH}_{4}$ in $0.1 \mathrm{M}$ Tris- $\mathrm{HCl}$ buffer (pH 7.4) without DNA and in the presence of increasing DNA concentrations $(10 \mu \mathrm{M}-90 \mu \mathrm{M})$ 


\section{Cyclic voltammetry}

Interaction of the PP-544- $\mathrm{NH}_{4}$ with DNA was confirmed electrochemically. Figure $4 B$ shows cyclic voltammograms of $5 \mathrm{mM}$ PP-544- $\mathrm{NH}_{4}$ alone and presence of increasing concentrations of DNA in 0.1 M Tris-HCl buffer, $\mathrm{pH}=7.4$. The peak current decreases upon the addition of increasing concentrations of DNA, owing to the binding of the 1,4-DHP. The compound exhibited a single well defined anodic peak, which corresponds to the oxidation of dihydropyridine ring [22]. In reverse scan no one peak was observed indicating that oxidation of the compound is an irreversible process. The binding constant of the compound calculated on the basis of electrochemical experiments was equal to $1.11 \times 10^{4}$, the compound should interact with 2 base pairs.

\section{Other biological activities of DNA-bind- ing 1,4-DHP}

It was interesting to compare DNA-binding capacities of the 1,4-DHP with other activities of the compounds.

\section{Decomposion of peroxynitrite in the} presence of 1,4-DHPS

It was revealed that the decomposition of peroxynitrite was slightly accelerated in [the] presence of J-4-186, J-7-53-B and J-8-120 (Table 1). The strong DNA binder tricyclic fused 1,4-DHP derivative $\mathrm{PP}-544-\mathrm{NH}_{4}$ produced a paradoxical kinetic curve - the optical density of peroxynitrite and DHP mixture increased with time. Apparently, the compound interacts chemically with peroxynitrite, the reaction product has absorbance peak in the area of peroxynitrite absorbance maximum (Fig. 5). However, we could not reveal any correlation between DNA binding and peroxynitrite scavenging capacities.

\section{Radical scavenging - EPR measure- ments}

The ability of the 1,4-DHP to scavenge other free radicals, namely $\mathrm{OH}$ radical produced in the Fenton reaction was tested by EPR method. We have tested both strong (PP-150-Na) and

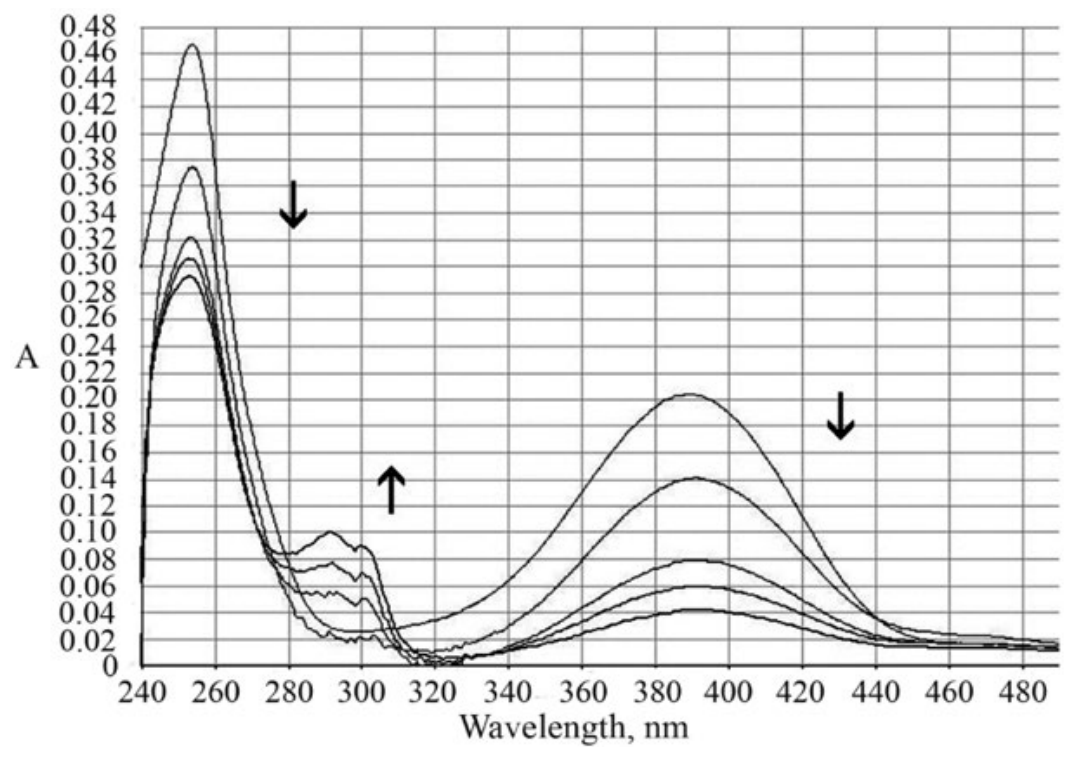

Fig. 5. Changes of the spectrum of $\mathrm{PP}-544-\mathrm{NH}_{4}$ in presence of peroxynitrite with time $(0-25 \mathrm{~min})$. Peroxynitrite was added also to the control cuvette. 
weak DNA binders (AV-154-Na, J-7-53, J-8120) at $1000 \mu \mathrm{M}$ concentration. The signals of the second component of EPR spectra were measured on the 3rd min $\left(\mathrm{I}_{3}\right)$ and 5 th $\min \left(\mathrm{I}_{5}\right)$ and the difference between them $\mathrm{I}_{3}-\mathrm{I}_{5}$ was calculated (Fig. 6A). Scavengers of $\mathrm{OH}$ radicals should increase the difference between $\mathrm{I}_{3}$ and $\mathrm{I}_{5}$. Representative kinetics of the decrease of EPR signal intensity is shown in Fig. $6 B$, results are summarized in Table 1 . As seen in Figure $6 B \mathrm{AV}-154$ does not interfere with the rate of the reaction, an impact of PP-150-Na is modest. Similar results were obtained for most other compounds. Thus, a correlation between radical scavenging and DNA-binding capacities was not observed. Moreover, some compounds, including one of the strongest DNA binders PP-544- $\mathrm{NH}_{4}$ increased intensity of the hydroxyl radical signal, indicating their pro-oxidant effect. It also turned out that J-496 and $\mathrm{J}-3-131-\mathrm{Na}$ react with $\mathrm{FeSO}_{4}$ and form the DMPO-OH radicals in the absence of
$\mathrm{H}_{2} \mathrm{O}_{2}$, B-5-Na and tauropyrone could not produce this reaction. Thus affinity to DNA of the 1,4-DHP does not correlate with radical scavenging capacity.

\section{DNA protection in vitro against damage} by radical produced in Fenton reaction

Ability of the tested compounds to protect plasmid DNA against induction of singlestrand breaks produced by radicals generated in Fenton reaction was tested by means of DNA electrophoresis in neutral conditions. The reaction produced a significant DNA damage $(p<0.0001 n=35-91)$. Some of the tested compounds produced a protecting effect. Some weak binders (J-7-53 and J-4-96) even enhanced the level of DNA breakage to some extent, however statistical significance was not reached (not shown). Thus in these series of experiments we could not detect a pronounced correlation between DNA-binding capacity and DNA protection.
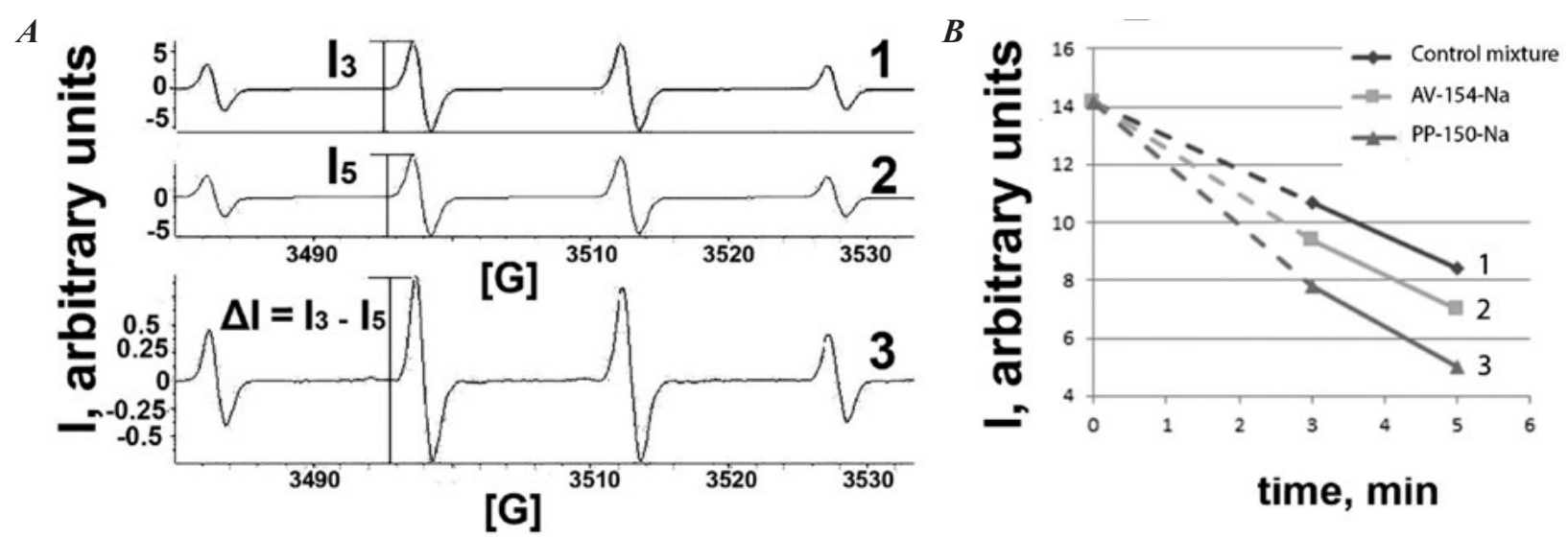

Fig. 6. $A$ - EPR spectra of DMPO-OH radicals generated in Fenton reaction in presence of DMPO. 1 - EPR spectra of DMPO-OH radicals 3 min after mixing the components for Fenton reaction. 2 - EPR spectra of DMPO-OH radicals 5 min after mixing the components for Fenton reaction. $\mathrm{I}_{3}$ and $\mathrm{I}_{5}-$ intensities of EPR signals used for quantification of DMPO-OH radicals at corresponding time. 3 - difference between 3 min and 5 min spectra indicating decrease of the signal intensity and lack of generation of other radicals. $B$ - time course of decrease of intensity of DMPO-OH radical spectra. 1 - control mixture; 2 - in presence of AV-154; 3 - in presence of PP-150-Na. 
Taken together, our data indicate that several 1,4-DHP derivatives can bind efficiently to DNA, affinity to DNA strongly depends on the structure of the derivative. 1,4-dihydropyridine with carboxylate groups in position-4 and with ethoxycarbonyl groups in positions 3 and 5 (AV-153) and fused tricyclic molecules appear to be the best DNA binders. Both intercalative and minor grove binding mechanisms are possible. No evident correlations between DNA binding and other activities of the compounds could be revealed.

\section{Acknowledgements}

The work was supported from the Inner grant of the Latvian Institute of Organic Synthesis IG-2018-02, State Research Program "Biomedicine 2014" and ECO-NET RUS programme project "DNA Parylation". We thank U. Kalnenieks and R. Rutkis (Institute of Microbiology and Biotechnology of the University of Latvia) for giving access to their equipment.

\section{REFERENCES}

1. Ryabokon NI, Goncharova RI, Duburs G, Rzeszows$k a$-Wolny $J$. A 1,4-dihydropyridine derivative reduces DNA damage and stimulates DNA repair in human cells in vitro. Mutat Res. 2005;587(1-2):52-8.

2. Ryabokon NI, Goncharova RI, Duburs G, Hancock R, Rzeszowska-Wolny J. Changes in poly(ADPribose) level modulate the kinetics of DNA strand break rejoining. Mutat Res. 2008;637(1-2):173-81.

3. Ryabokon NI, Cieślar-Pobuda A, Rzeszowska-Wolny J. Inhibition of poly(ADP-ribose) polymerase activity affects its subcellular localization and DNA strand break rejoining. Acta Biochim Pol. 2009;56(2):243-8.

4. Ryabokon NI, Nikitchenko NV, Dalivelya OV, Goncharova RI, Duburs G, Konopacka M, RzeszowskaWolny J. Modulation of cellular defense processes in human lymphocytes in vitro by a 1,4-dihydropyridine derivative. Mutat Res. 2009;679(1-2):33-8.
5. Keles MS, Bayir Y, Suleyman H, Halici Z. Investigation of effects of Lacidipine, Ramipril and Valsartan on DNA damage and oxidative stress occurred in acute and chronic periods following isoproterenolinduced myocardial infarct in rats. Mol Cell Biochem. 2009;328(1-2):109-17.

6. López-Alarcón C, Speisky H, Squella JA, OleaAzar C, Camargo C, Núñez-Vergara LJ. Reactivity of 1,4-dihydropyridines toward SIN-1-derived peroxynitrite. Pharm Res. 2004;21(10): 1750-7.

7. Lob H, Rosenkranz AC, Breitenbach T, Berkels R, Drummond $G$, Roesen $R$. Antioxidant and nitric oxide-sparing actions of dihydropyridines and ACE inhibitors differ in human endothelial cells. Pharmacology. 2006;76(1):8-18.

8. Pal S, Singh V, Das P, Choudhury LH. PEG-mediated one-pot multicomponent reactions for the efficient synthesis of functionalized dihydropyridines and their functional group dependent DNA cleavage activity. Bioorg Chem. 2013;48:8-15.

9. Hyvönen Z, Plotniece A, Reine I, Chekavichus B, Duburs G, Urtti A. Novel cationic amphiphilic 1,4-dihydropyridine derivatives for DNA delivery. Biochim Biophys Acta. 2000;1509(1-2):451-66.

10. Lin SJ, Lu HK, Lee HW, Chen YC, Li CL, Wang LF. Nitric oxide inhibits androgen receptor-mediated collagen production in human gingival fibroblasts. J Periodontal Res. 2012;47(6):701-10.

11. uraka E, Chen $C Y$, Gavare $M$, Grube M, Makarenkova $G$, Nikolajeva V, Bisenieks I, Brūvere I, Bisenieks E, Duburs G, Sjakste N. DNA-binding studies of AV-153, an antimutagenic and DNA repair-stimulating derivative of 1,4-dihydropiridine. Chem Biol Interact. 2014;220:200-7.

12. Leonova E, Sokolovska J, Boucher JL, Isajevs S, Rostoka E, Baumane L, Sjakste T, Sjakste N. New 1,4-Dihydropyridines Down-regulate Nitric Oxide in Animals with Streptozotocin-induced Diabetes Mellitus and Protect Deoxyribonucleic Acid against Peroxynitrite Action. Basic Clin Pharmacol Toxicol. 2016;119(1):19-31.

13. Robinson KM, Beckman JS. Synthesis of peroxynitrite from nitrite and hydrogen peroxide. Methods Enzymol. 2005;396:207-14. 
14. Zhang S, Sun X, Jing Z, Qu F. Spectroscopic analysis on the resveratrol-DNA binding interactions at physiological pH. Spectrochim Acta A Mol Biomol Spectrosc. 2011;82(1):213-6.

15. Chen W, Li Y, Li J, Han $Q$, Ye L, Li A. Myricetin affords protection against peroxynitrite-mediated DNA damage and hydroxyl radical formation. Food Chem Toxicol. 2011;49(9):2439-44.

16. Ošinga K, Leonova E, Isajevs S, Baumane L, Rostoka E, Sjakste T, Bisenieks E, Duburs G, Vìgante B, Sjakste N. Modifications of expression of genes and proteins involved in DNA repair and nitric oxide metabolism by carbatonides [disodium-2,6-dimethyl-1,4-dihydropyridine- 3,5-bis(carbonyloxyacetate) derivatives] in intact and diabetic rats. Arh Hig Rada Toksikol. 2017;68(3):212-227.

17. Carballal S, Bartesaghi S, Radi R. Kinetic and mechanistic considerations to assess the biological fate of peroxynitrite. Biochim Biophys Acta. 2014; 1840(2):768-80.

18. Vijesh AM, Isloor AM, Peethambar SK, Shivananda KN, Arulmoli T, Isloor NA. Hantzsch reaction: synthesis and characterization of some new 1,4-dihydropyridine derivatives as potent antimicrobial and antioxidant agents. Eur J Med Chem. 2011; 46(11):5591-7.

19. Shamsuzzaman, Dar AM, Khan Y, Sohail A. Synthesis and biological studies of steroidal pyran based derivatives. $J$ Photochem Photobiol B. 2013;129:36-47.

20. Rescifina A, Zagni C, Varrica MG, Pistarà V, Corsaro $A$. Recent advances in small organic molecules as DNA intercalating agents: synthesis, activity, and modeling. Eur J Med Chem. 2014;74:95-115.

21. Palchaudhuri R, Hergenrother PJ. DNA as a target for anticancer compounds: methods to determine the mode of binding and the mechanism of action. Curr Opin Biotechnol. 2007;18(6):497-503.

22. Augustyniak A, Bartosz G, Cipak A, Duburs G, Horáková L, Luczaj W, Majekova M, Odysseos AD, Rackova L, Skrzydlewska E, Stefek M, Strosová M, Tirzitis G, Venskutonis PR, Viskupicova J, Vraka PS, Zarković $N$. Natural and synthetic antioxidants: an updated overview. Free Radic Res. 2010;44(10): 1216-62.
Дослідження взаємодії з ДНК серії нових водорозчинних похідних 1,4-дигідропіридину

Е. Леонова, Е. Ростока, Л. Баумане, І. Борисовс, Е. Смеловс, І. Бісеніекс, І. Брувере, Е. Бісеніекс, Г. Дубурс, Н. Сьяксте

Мета. Дослідження способу взаємодії з ДНК серії синтезованих в Латвійському університеті органічного синтезу 1,4-ДГП з різною біологічною активністю. Методи. Спорідненість речовин до ДНК визначалося спектрофотометрично і було перевірені ще спектрофлуоріметрічно за виштовхуванням бромистого етидія, циклічної вольтамметріі і за плавленням ДНК. Здатність речовин зв'язувати пероксинітрит визначали спектрофотометрично, здатність пов'язувати гідроксильних радикалів - методом електронного парамагнітного резонансу, здатність захищати ДНК від ушкодження цим радикалом - методом електрофорезу. Результати. У серії водорозчинних моноциклических 1,4-ДГП з карбоксилатного групою у позиції 4, різна спорідненість до ДНК визначалося в основному замысниками у позиціяx 3 і 5. 1,4-ДГП з етоксікарбонільним групами у позиціях 3 і 5 (AV-153) ефективно зв'язувався з ДНК. Сильні ефекти спостерігали в спектрах з'єднаних трициклічних похідних 1,4-ДГП (PP-150-Na i PP-544-NH4). На відміну від AV-153, J-4-96 витісняють бромистий етидій $з$ комплексу з ДНК, що вказує на зв'язування цього з'єднання з малої борозенкою ДНК. За даними електрохімічних досліджень і кривих плавлення ДНК PP-544-NH4 повинен інтеркалювати в ДНК. Нам не вдалося зв'язати спорідненість до ДНК зі здатністю речовин зв'язувати пероксинітрит, гідроксильний радикал або захищати ДНК від ушкодження цим радикалом. Висновки. Спорідненість 1,4-ДГП до ДНК визначаються замісниками у позиції 3 і 5 . Добре зв'язуються з ДНК також трициклічні 1,4-ДГП. Спорідненість 1,4-ДГП до ДНК не корелює з іншими активностями з'єднання

\section{Исследование взаимодействия с ДНК серии новых водорастворимых производных 1,4-дигидропиридина}

Э. Леонова, Э. Ростока, Л. Баумане, В. Борисовс, Э. Смеловс, И. Бисениекс, И. Брувере, Э. Бисениекс, Г. Дубурс, Н. Сьяксте

Цель. Целью настоящего исследования было исследование образа взаимодействия с ДНК серии синтези- 
рованных в Латвийском институте органического синтеза 1,4-ДГП с различной биологической активностью. Методы. Сродство веществ к ДНК опредедялось спектрофотометрически и было перепроверено спектрофлуориметрически, по выталкиванию бромистого этидия, циклической вольтамметрии и по плавлению ДНК. Способность веществ связывать пероксинитрит определяли спектрофотометрически, способность связывать гидроксильный радикалил - методом электронного парамагнитного резонанса, способность защищать ДНК от повреждения этим радикалом - методом электрофореза. Результаты. В серии водорастворимых моноциклических 1,4-ДГП с карбоксилатной группой в позиции 4, различное сродство к ДНК определялось в основном заместителями в позициях 3 и 5. 1,4-ДГП с этоксикарбонильным группами в позициях 3 и 5 (AV-153) эффективно связывался с ДНК. Сильные эффекты наблюдали в спектрах соединенных трициклических производных 1,4-ДГП (РP-150-Na и PР-544-
NH4). В отличие от AV-153, J-4-96 не вытеснял бромистый этидий из комплекса с ДНК, что указывает на связывание этого соединения с малой бороздкой ДНК. По данным электрохимических исследований и кривых плавления ДНК РP-544-NН 4 должен интеркалировать в ДНК. Нам не удалось связать сродство к ДНК со способностью веществ связывать пероксинитрит. гидроксильный радикал или защищать ДНК от повреждения этим радикалом. Обсуждение. Сродство 1,4-ДГП к ДНК определяются заместителями в позицих 3 и 5. Хорошо связываются с ДНК также трициклические 1,4-ДГП. Сродство 1,4-ДГП к ДНК не коррелирует с другими активностями соединения.

К л юч е в ы е с л о в а: 1,4-дигидропиридины, связывание с ДНК, связывание пероксинитрита, связывание с гидроксильного радикала, защита ДНК.

Received 10.10.2017 